\title{
The Effect of Capital Competence on the Jordanian Banks Profitability
}

\author{
Ahmad Zakaria Siam ${ }^{1} \&$ Ibrahim Marwan Khanji ${ }^{1}$ \\ ${ }^{1}$ Finance and Banking Department, Al Balqa Applied University, Jordan \\ Correspondence: Ahmad Zakaria Siam, Finance and Banking Department, Al Balqa Applied University, Jordan. \\ E-mail: siam_ahmad@hotmail.com
}

Received: March 2, 2015

Accepted: March 23, 2015

Online Published: May 25, 2015

doi:10.5539/ijef.v7n6p243

URL: http://dx.doi.org/10.5539/ijef.v7n6p243

\begin{abstract}
This study aims at investigating the effect of capital competence on the Jordanian commercial banks' profitably through two measurements: capital competence versus total assets and capital competence versus risk assets. In regard to profitability it has been measured through return on investment (ROA), return on Equity (ROE) and return on share (EPS).

In order to achieve the objectives of the study, a statistical test is conducted through the use of linear regression coefficient and the use of SPSS. The study revealed several results, and is concluded with recommendations, which assures the effect of capital competence on the Jordanian commercial banks profitability in facing risk and enhancing liquidity in order to achieve financial solidity.
\end{abstract}

Keywords: capital competence, commercial banks, financialconsolidation, profitability.

\section{Introduction}

Capital competence is increasingly gaining importance day after day, in the midst of accelerating events of money and business, and focusing on having banks to reserve a minimum level of its own resources so as to counter risks, and to organize relationship between capital and deposits on the basis of having liquidity and profitability that go side by side but in a contradicting manner. Because of this condition and because of commercial banks performance started to retrograde, Basel agreement has been founded; to loans and facilities. Furthermore, Basel has other general objectives such as: support financial and banking sectors to strengthen them through modernizing and updating methods, and approaches for risk management. Therefore, capital competence has become the main indicator for banks ability and competency in need decision making for pricing banking services, risk monitoring and enhance commercial banks profitability.

Therefore, commercial banks have been obliged to preserve the minimum level of capital competency to counter risks that banks may be subjected to, and in accordance with determined measures which reflect the capital competency the banks owns, to absorb any losses may face that bank. This will be according to what is known by the ratio of total capital Assets and the reliance extent on equity rights to finance assets. Moreover, there is what is known by equity rights to risk assets ratio when discussing the risk of: loans, securities, and long-term investment that carry high risks which reflects- in one way or another, assets that are difficult to turn into cash without losses.

This reflect liquidity terminology that expresses ready cash or equity liquidity which means, easy and rapid transfer into cash such assets can be ready cash without losses what so ever, and according to ordinary processes of financial issues. (Haddad, 2014, p. 21).

Most recently, numerous authors have started examining banks profitability and the determinants which affect this profitability (Jarrah, Ziadat, \& Rimawi, 2010; Ramadan, Kilani, \& Kaddumi, 2011) and other, these authors discussed the impact of several factors that influence banks profitability such as: Return on assets, (ROA) return on equity (ROE) and other elements. However, this study discusses banks capital competency or well-capitalized banks on their profitability.

While Jordan is considered to be one of the pioneer countries in applying international standards, therefore, the Jordanian commercial banks sector has experienced quantitative and qualitative growth in recent years which positively reflect on financial crises consequences. 
The Jordanian banking sector enjoys a safe liquidity, whereas the cash deposits in these banks reached up to 26 percent of total assets, comparing to 50 percent in 2013 and 49 percent in 2012. At the same time covering of non-active loan allotted (covering percent) went up to reach 78,2 percent by the end of 2013. Therefore, these performance indicators reflected positively on the percent of capital competency; whereas, it is the highest in the middle East and North Africa, which is around 18 percent to 20 percent between the years 2007-2013. These figures are higher than the percent, which the Jordanian central Bank has determined, 12 percent and higher than Basel's $8 \%$.This means that there is a substantial closeness between capital competency percent and primary capital's. This leads to the strengthening of financial stability and assures a greater extent the ability to absorb losses.

This indicates that banks follow the reservation approach in its dealing by not jumping into risk practices. Therefore, the magnitude of banks investment in the Jordanian governments bonds reaches up to 8,903 million dinar with Zero risk constitutes $21 \%$ of banks total assets.

While the Jordanian commercial are not far away from surrounding risk, it is expected from these banks to be more careful in applying and strengthening the capital competency percent by which it may achieve several positivity in general and benefits for profitability in particular.

Consequently, authors determined to study the effect of capital competency on the Jordanian commercial banks profitability in order to reveal the ideal applicability and positive consequence on financial performance solidity and profitability.

\subsection{Significance and the Objectives of the Study}

This study is considered to be important for several reasons: it discusses the population of the Jordanian commercial banks listed in Amman Stock Exchange; in addition, this study is the first study that disuses the effect of capital competency to (total assets) from one aspect and to (risk assets) from the other, on commercial banks profitability measured by three ratios: return on assets (ROA), return on equity (ROE) and return on shares (EPS).

\subsection{Objectives of the Study}

This study aims at investigating the effect of capital competency on the Jordanian commercial banks listed on Amman Stock Exchange profitability through the achievement of the following objectives:

Investigating the effect extent of capital competency to total assets on Jordanian commercial banks profitability measured by return on assets (ROA).

Investigating the effect extent of capital competency to total assets on Jordanian commercial banks profitability measured by return on equity (ROE).

Investigating the effect extent of capital competency to total assets on Jordanian commercial banks profitability measured by return on shares (EPS).

Investigating the effect of capital competency to total risk assets on Jordanian commercial banks' profitability measured by return on assets (ROA).

Investigating the effect extent of capital competency to total assets on Jordanian commercial banks profitability measured by return on equity (ROE).

Investigating the effect extent of capital competency to total assets on Jordanian commercial banks profitability measured by return on share (EPS).

\subsection{The Problem of the Study}

This study seeks to reveal the effect of capital competency on Jordanian commercial banks profitability through answering the following question:

What is the effect of capital competency (to total assets on Jordanian commercial banks profitability measured by return on asset (ROA)?

What is the effect extent of capital competency to total assets on Jordanian commercial banks profitability measured by return on equity (ROE)?

What is the effect extent of capital competency to total assets on Jordanian commercial banks profitability measured by return on share (EPS)?

What is effect extent of capital competency (to risk assets) on commercial banks profitability measured by return on assets (ROA)? 
What is the effect extent of capital competency (to risk assets) on commercial banks profitability measured by return on equity (ROE)?

What is the effect extent of capital competency (to risk assets) on commercial banks profitability measured by (EPS)?

\subsection{Theoretical Framework and Previous Studies}

Commercial banks are the backbone of banking system due to the vital role they play in banking arena. As a result, banks are facing several challenges in order to gain customers trust and the solidity of their financial condition in the midst of rapid moving environment. Thus, banks are obligated to adhere to international banking standards, and be obliged to capital competency standard according to Basel committee in general and the central bank's instructions in particular.

Capital competence of a bank or well-capitalized bank is the way the bank finances its assets across several elements of debt, equity or hybrid securities (Taan, 2013). It is a combination of debt and equity that makes the total capital of a bank. From this principle and to achieve the objectives of the study.

Capital competence is worthy for exploring in Jordanian banks for several reasons:

1) Commercial Jordanian banks concentrate its investment activities and practices on local projects and facilities mainly: loans to government and buying American Treasury bills.

2) Capital competency is utilized by local banks in Jordan to be an effective instrument in investing in local large projects so as to generate substantial profits with minimum risk. That is why author has chosen the variables of capital competency to total assets and capital competency to total risk assets.

Capital as being banks' security line and the fortifying its financial position, it is a means to protect depositors through provide guarantees for their rights, and a bank's protective shield to confront and countering potential loss. In addition, capital competence is the indicator that reflects the trust of those who deal with banks and its creditors as well. Consequently, this means risks market and operation. Moreover, the significance of capital competency stems from organizing the relationship between capital in one side, and deposits in other: Also having the bank withholds the minimum level from its own money to counter and control risks for the purpose of pricing banking service, enhance returns which positively reflects on banks' capital competency, and enhancing banks' competitive ability in order to protect their financial position and competitiveness.

Thus, banks should maintain review processes and comprehensive assessment for capital competency, guarantee their obligation towards staying within legal averages of capital, and prevent capital lowering beyond required minimum level to counter losses, through early intervention and taking necessary steps to maintain the required limits by determining total ratios of capital and its components, which is in accordance with banking transparency and precaution monitoring. As results the issue of capital competency has become significant by banks and monitoring apparatuses. Whatever concepts or terminology used in this context, all show agreement over relationship between the capital sources and risk for being as a measurement instrument for capital competency (Mekhlafi, 2004; Barakat, 2009).

Previous studies point out to the necessity for commercial banks to enhance their financial positions through the application of capital competency measurement which represents the required level of financial safety and security (Taib \& Shateet, 2011). The ratio of operation casts to total assets and the average of risk assets to total assets and the banking focus degree have relationship with the capital (Abu Fahkrah, 1997).

Thus, commercial banks competency is linked, to a greater degree, with banks productivity and profitability within money and credit policies and within commercial banks financial statements. Moreover, the commercial banks' performance, to a greater degree, relies on the increase in their capitals and to employ such capitals ideally within banking position and cash and reserve's demand. This reflects on the competition and profitability degree, within the belief that banks success, achieve their competition and enhancing their profitability are all affected by bank's size competition degree among bank themselves (Llewellyn, 2005).

Furthermore, previous studies revealed the applicability of capital competency limits, therefore positive results can be achieved at liquidity and profitability size and minimizing risks. Consequently, banks competition is enhanced in a way that guarantees financial solidity and banking safety (Siam, 2012).

The aforementioned reveals the capital competency significance of the Jordanian commercial banks, considering it as an active instrument to face risks, preventing and minimizing risks and enhance banks' competition.

In addition, the positivity's of enhancing capital competency shall increase deposited funds protection and increase trust with depositors and creditors as well. Consequently, a kind of balance between potential risks and 
the size of capital is achieved (Saudi, 1999). This assures the necessity to have serious attitude towards banks' capital increase in a way that goes parallel with banking potential risks and the application of capital competency standard. (Abdel Fatah, 2013).

\subsection{Determinants of the Jordanian Banks' Profitability}

Central bank of Jordan has played significant role in the substantial developments during the past few decades. One of these development, is to transfer banking sector in Jordan from the wealthy families dominance on certain banks: (Arab Banks vs. Shuman family; Ahli Bank vs. Muusher gamily and others), into modern up to date banking systems through competent supervisory and regulatory roles, as well as following the latest global financial practices. As a result, banking sector in Jordan, plays a key role in Jordan by pushing forward growth rates through national savings and using them to finance productive economic sectors. For example, during the period (2003-2010) the work of banks recorded a strong growth reached at end of the first half of 2010 to JD 32.5 billion or 45.9 billion American dollars. (Central Bank Report, 2011) Furthermore; determinants of bank profitability have received much attention from academic researchers:

Authors; Ramadan, Kilani, and Knddumi (2011) conducted a research in this context entitled Determinants of Bank profitability: Evidence from Jordan. So as to investigate the nature of the relationship between the profitability of banks and the characteristics of internal and external factors. They used ROA and ROE as measurements of bank's profitability. Results of the study indicated that, Jordanian banks' characteristics explain a significant part of the variation of bank profitability high Jordanian bank profitability tends to be associated with well-capitalized banks...

Taani (2013), from different angle adds, capital structure and profitability of banks in Jordan. Banks performance which is measured by net profit, return on capital employed and net interest margin is to be significantly and positively associated with total debt.

Alkhazaleh and Al Msafir (2014) examined bank specific determinants of profitability in Jordan such as: capital structure, bank size and liquidity. Results of their study indicate that the capital structure of the bank, the bank size as well liquidity contribute to banks' profitability.

From Jordan to Malaysia where Jamal, Karim, and Himidi (2014) conducted a study by the title of "Determinants of commercial Banks' return on Asset (Malaysia)". In their study authors attempted to investigate the possible influence of macroeconomics factors on domestic and foreign banks' profitability.

The results of the study indicate that all the external factors namely: inflation, indirect rate of GDP have a positive impact on all commercial banks' return on assets

Lee and Hsieh (2013) focus in their research on the impacts of bank capital on profitability and risks. Authors reached the following results:

1) Banks in low-income countries have a higher capital effect on profitability.

2) Banks in Middle Eastern countries own the highest and positive capital effect on profitability.

Jorrah et al, 2010 found out that the most important internal determinants of the bank's profitability are the loans to total assets ratio, the operating expenditure ratio, the capital structure and other. Finally, profitability of Jordanian's banks does not respond speedily to change in the explanatory variables in the short-run.

Jalman (2013) uses financial ratios in determining factors affect banks profitability in Iraq. Author found that, assets size capital competency, loans, equity and cash flow, have significant impact on banks profitability.

Finally, current study will contribute to literature relevant to determinants effect on bank's profitability in Jordan.

\subsection{Hypotheses of the Study}

Based upon theoretical framework and previous studies and in accordance with the study's objectives, the following hypotheses are developed and be tested,

Ho1: there is no statistically significant relationship between capital competency to total assets and the profitability of the Jordanian commercial banks (ROA).

Ho2:thereis no statistically significant relationship between capital competency to total assets and the profitability of the Jordanian commercial banks (Return on Equity).

Ho3: there is no statistically significant relationship between capital competency to total assets and the profitability of the Jordanian commercial banks (Return on share).

Ho4: there is no statistically significant relationship between capital competency to total risk assets and the 
profitability of the Jordanian commercial banks (ROE).

Ho5: there is no statistically significant relationship between capital competency to total assets and the profitability of the Jordanian commercial banks (to risk total assets).

Ho6: there is no statistically significant relationship between capital competency to total assets and the profitability of the Jordanian commercial banks (To risk assets).

\subsection{Population and the Sample of the Study}

The study population consists of all commercial banks operating in Jordan, while the sample of the study consists of all banks listed in Amman stock Exchange as shown in Table 1:

Table 1. Study's participating banks

\begin{tabular}{|c|c|c|c|}
\hline No. & Bank & Capital competency & Return on assets $\%$ \\
\hline 1 & Arab Bank & 16 & 1.41 \\
\hline 2 & Housing Bank & 14 & 1.48 \\
\hline 3 & Ahli Bank & 10 & 0.6 \\
\hline 4 & Mal Bank & 17 & 1.5 \\
\hline 5 & Bank of Jordan & 15 & 1.75 \\
\hline 6 & Jordanian Islamic Bank & 7,5 & 1.13 \\
\hline 7 & Itihad Bank & 13 & 1.17 \\
\hline 8 & Societe General Bank & 17 & 1.09 \\
\hline 9 & ABC Bank & 14 & 1.22 \\
\hline 10 & Arab investment Bank & 16 & 1.39 \\
\hline 11 & Jordan-Kuwaiti Bank & 16 & 1.86 \\
\hline 12 & Cairo-Amman Bank & 12 & 1.84 \\
\hline 13 & Investment Bank & 18 & 1.53 \\
\hline 14 & Islamic Jordan-Dubai Bank & 25 & 0.28 \\
\hline 15 & Jordanian Trade Bank & 11 & 0.3 \\
\hline
\end{tabular}

Source: Bank annual statements.

\section{Data Collection Methods}

In addition to relevant books, research, published studies and journals, it has been relied on analytical approach besides other statistical analyses approaches and banks annual financial statements for the years 2010-2013.

Statistical analysis is used to test study's hypotheses' creditability and accuracy, through Regression equation.

\subsection{Regression Equation Formula}

When we reviewed linear functions, we described equations of the type, $\mathrm{Y}=.75 \mathrm{X}+3$. Then we put in values of $\mathrm{X}$, calculated values of $\mathrm{Y}$, and drew the line on a graph. But what if we don't know the values of the parameters a and b?

In Regression analysis we don't know a and $b$. We have to calculate a value of a and a value of $b$ from the sample data. We're going to use the data to calculate the slope and the intercept of the regression line.

The current graphic shows the formulas for calculating the slope and the intercept from the data. Our estimated value of $Y$ will be found through the equation $Y^{\prime}=a+b X$ The yellow box on the left shows the formulas for a and b.

The intercept, $\mathrm{a}$, is equal to the Mean of X minus b times the Mean of Y.

The slope, $b$, is equal to the correlation coefficient, $r$, times the standard deviation of $\mathrm{Y}$ divided by the standard deviation of $\mathrm{X}$.

Note: we can reverse the predictor variable and the criterion variable. That is reverse $\mathrm{X}$ and $\mathrm{Y}$ so to predict $\mathrm{X}$ from $\mathrm{Y}$ instead of $\mathrm{Y}$ from $\mathrm{X}$. In this example, that means predict the size of profits (X) from the capital (Y). The pink box in the lower right of the graphic shows the formulas for predicting $\mathrm{X}$ from $\mathrm{Y}$.

\subsection{Linear Regression}

Linear regression attempts to model the relationship between two variables by fitting a linear equation to 
observed data. One variable is considered to be an explanatory variable, and the other is considered to be a dependent variable. For example, a modeler might want to relate the weights of individuals to their heights using a linear regression model.

Before attempting to fit a linear model to observed data, a modeler should first determine whether or not there is a relationship between the variables of interest. This does not necessarily imply that one variable causes the other (for example, higher SAT scores do not cause higher college grades), but that there is some significant association between the two variables.

A linear regression line has an equation of the form $\mathrm{Y}=\mathrm{a}+\mathrm{bX}$, where $\mathrm{X}$ is the explanatory variable and $\mathrm{Y}$ is the dependent variable. The slope of the line is $b$, and a is the intercept (the value of $y$ when $x=0$ ). (Source: Google accessed on 15/3/2015).

Author has used these complicated formulas in calculating the relationship with independent and dependent variables of the study.

\section{Data Analysis and Hypotheses Testing}

To test the hypotheses acceptability linear regression coefficient is used, with the use of SPSS so as to find out the effect extent of capital competency to total assets (X1), and capital competency to risk assets (X2) as independent variables on bank's profitability as dependent variable (Y).

The linear regression equation determines the coefficient value which shows the effect extent of the independent variable on the dependent variable through the equation $B$, and the value (SIG) and (R) coefficient between variables, in addition to $\mathrm{R} 2$ testing to explain change ratio in profitability as a result of change in capital competency.

\subsection{Variables of the Study}

\section{First: dependent variable:}

Represents commercial banks' profitability, which is measured by: Return on assets, return on equity and return on shares, each of these is represented by the dependent variable (Y).

\section{Second: Independent variables:}

Capital competency to total of assets (X1).

Capital competency to risk assets (X2).

Testing First Hypothesis.

Ho1: there is no statistically significant relationship between capital competency versus total assets and the Jordanian commercial banks profitability (Return on assets).

\begin{tabular}{lllll}
\hline ROA & constant & B & R2 & SIG \\
\hline Capital/Assets & 1.16 & 0.351 & 0.16 & 0.02 \\
\hline
\end{tabular}

The statistical analysis shows the presence of positive statistically relationship between capital competency (to total assets) and return on assets of commercial banks, whereas, the value of (SIG) is 0.02 which means the acceptance of alternative hypothesis at $\alpha=0,05$ and the value of $\mathrm{R}=0,16$.

This results proves that capital competency intercepts $16 \%$ of change in the average of return on assets.

\section{Second hypothesis testing:}

Ho2: there is no statistically significant relationship between capital competency to total assets and the profitability of the Jordanian commercial banks (Return on Equity).

\begin{tabular}{lllll}
\hline ROE & constant & B & R2 & SIG \\
\hline Capital/Assets & 15.1 & -0.41 & 0.19 & 0.01 \\
\hline
\end{tabular}

The statistical analysis shows the presence of negative statistically significant relationship between capital competency (versus total assets) and bank' return on equity whereas sig $=0.01$. This means the acceptance of the alternative hypothesis at $\alpha=0.05$; and $\mathrm{R}=0.19$. This result also shows that capital competency intercepts $19 \%$ of change in return on equity. 


\section{Third Hypothesis testing:}

Ho3: there is no statistically significant relationship between capital competency to total assets and the profitability of the Jordanian commercial banks (Return on share).

\begin{tabular}{lllll}
\hline EPS & constant & B & R2 & SIG \\
\hline Capital/Assets & 0.367 & $0.97-$ & 0.13 & 0.08 \\
\hline
\end{tabular}

Statistical analysis shows the presence of negative statistically significant relationship between capital competency (to total assets) and EPS of commercial banks with sig $=0.08$. This means the acceptance of the alternative hypothesis at $\alpha=0.010, \mathrm{R}=0.13$ thus capital competency intercepts $13 \%$ of change in EPS.

\section{Fourth Hypothesis testing:}

Ho4: there is no statistically significant relationship between capital competency to total assets and the profitability of the Jordanian commercial banks (return on assets).

\begin{tabular}{lllll}
\hline ROA & constant & B & R2 & SIG \\
\hline Capital/risk Assets & 1.65 & 0.58 & 0.07 & 0.57 \\
\hline
\end{tabular}

Statistical analysis shows that there is no statistically significant relationship between capital competences (to total risk assets).And ROA of commercial banks whereas:

$\mathrm{Sig}=0.57$ at which means the acceptance of the original hypothesis at $\alpha=0.05, \mathrm{R}=0.13$. Consequently, capital competency to total risk assets has no statistically significant which shows the presence of statistically significant effect of capital competency to total assets on ROA.

\section{Fifth Hypothesis testing:}

Ho5: there is no statistically significant relationship between capital competency to total assets and the profitability of the Jordanian commercial banks (return on equity).

\begin{tabular}{lllll}
\hline ROE & constant & B & R2 & SIG \\
\hline Capital/risk Assets & 14.42 & -0.28 & 0.133 & 0.013 \\
\hline
\end{tabular}

Statistical analysis revealed the presence of negative statistically significant relationship between capital competency to total assets and return on equity of Jordanian Banks, whereas sig $=0.013$. this means to accept the alternative hypothesis at $\alpha=0,05, \mathrm{R}=0.133$ this result shows that capital competency to total risk assets intercepts $13.3 \%$ of change in ROE.

\section{Sixth Hypothesis testing:}

Ho6: there is no statistically significant relationship between capital competency to total assets and the profitability of the Jordanian commercial banks (EPS).

\begin{tabular}{lllll}
\hline EPS & constant & B & R2 & SIG \\
\hline Capital/risk Assets & 0.253 & -0.129 & 0.03 & 0.71 \\
\hline
\end{tabular}

Statistical analysis shows that there is no statistically significant relationship between capital competency (to total risk assets) and EPS of banks, where $\mathrm{Sig}=0.71$ this means the original hypothesis acceptance at $\alpha=0.05$, $\mathrm{R}=0.03$ this results also shows that capital competency to total risk asset has no statistically significant effect on EPS. In contrast with the third hypothesis which shows negative statistically significant of capital competency to total risk assets on EPS average.

\section{Results of the Study}

\subsection{Current Study Reached the Following Results}

There is a positive statistically significant relationship between capital competency (to total assets) and ROA. These results are concurrent with previous studies. In turn, the lack of statistically significant relationship between capital competency (to total risk assets) and banks' ROA, means that there is no accurate capital (to risk assets) measurement.

There is a negative statistically significant relationship between capital competency (to total risk assets) and ROE of banks. In addition to negative statistically significant relationship between capital competency (to total 
risk assets) and ROE of Banks. This result indicates a decrease in ROE during the study's period.

There is a negative statistically significant relationship between capital competency (to total risk assets) and EPS, in turn, there is no statistically significant relationship between capital competency (to total risk assets) and banks' EPS.

\subsection{Recommendations}

Enhancing the Jordanian commercial bank capital competency through the increase in their capitals in order to face risk, and secure financial solidity, even through resorting to bank merging.

Enhancing the balance between expected risks and capitals size because of transparency and banking discipline.

It is necessary to have bankers be aware of the importance of bank's capital competency; clarify its rules and foundations, and the measurement of capital competence.

Conduct further studies using measurement tools and other variables for each of capital competency and profitability. It is possible in these further studies to use capital: deposits return: investment and loan.

Conduct further studies for other periods of time in order to reveal the role of capital competency in banks' profitability, whereas the period of this study occurred right after the banks started recovering from global financial crisis.

\section{References}

Abdul, J. A. A., Hamidi, M., \& Abdul, K. M. R. (2012). Determinants of commercial Banks Return on Asset: Panel evidence from Malaysia. International Journal of Commerce and Management, 1(3).

Abu Fakhrah, S. (1997). Relationship between profitability and capital competence in Jordan. Economic Science Journal, 2.

Alkhazalen, A. M., \& Al Msafir, M. (2014). Bank specific Determinants of profitability in Jordan. Journal of Advanced Social Research, 4(10).

Amman Stock Exchange. (n.d.). Shareholding companies Guide Amman-Jordan.

Barakat, A. (2009). Banks Basel II Norms Requirement Regading Internal Control Field Study on Jordan Banks. Delhi Business Review, 10(2).

Haddad, F. (2014). Financial Management. Hamed publishers Amman, Jordan.

Jarrah, I., Ziadat, K. H., \& Rimawi. (2010). The Determinants of the Jordanian's Banks profitability: A Co integration Approach. Jordan Journal of Business Administration, 6.

Jordan Central Bank. (2013). Financial Stability Report Amman, Jordan.

Lee, H., \& Hsieh, D. (2013). The impact of bank capital on profitability and risk in Asian banking. Journal of International Money and Finance, 32(8), 251-281. http://dx.doi.org/10.1016/j.jimonfin.2012.04.013

Llewellyn, D. T. (2005). Competition and Profitabilityin European Banking: Why are British Banks So Profitable? Economic Notes by Banca Monte dei Paschi di Siena S.P.A.

Meckhafi, A. (2004). Banks capital competence analysis-Yemeni banks-Yemen.

Ramadan, I., Kilani, Q., \& Kaddumi, T. (2011). Determinants of Bank profitability: Evidence from Jordan. International Journal of Academic Research, 3(4).

Salman, I. (2013). The use of financial Ratios in determining factors affecting banks' profitability. Economic Science Journal, 8(32).

Saudi, J. (1999). Fundamentals in financial system. Amman-Jordan: Wael publishers.

Siam, A. Z. (n.d.). The effect of capital competence and Basel application on Islamic banks competitiveness finance and trade Journal. Faculty of Business, (3).

Taib, S., \& Shateet, M. (2011). Measurement analysis to apply capital competence on commercial banks in Jordan Business science studies. Journal Amman, 28(2).

Teani, K. (2013). Capital structure effects on Banking performance a case study of Jordan. International Journal of Economics, Finance and Management. http://dx.doi.org/10.11648/j.ijefm.20130105.13 


\section{Appendix A. Jordanian Commercial Banks Statement}

\begin{tabular}{ccccc}
\hline Banks sector & 2010 & 2011 & 2012 & 2013 \\
\hline Total assets & $48,477,966,019$ & $50,516,950,642$ & $52,024,825,201$ & $54,912,998,990$ \\
Total risk assets & $24,621,954,823$ & $25,300,663,917$ & $27,413,853,757$ & $29,263,037,426$ \\
Payables total & $41,313,985,784$ & $43,156,869,098$ & $44,356,875,789$ & $46,883,048,480$ \\
Total shareholders' rights & $7,021,599,386$ & $7,207,014,190$ & $7,510,300,753$ & $7,852,486,395$ \\
Net profit & $476,357,885$ & $589,930,322$ & $635,748,300$ & $766,137,413$ \\
EPS & 0.22 & 0.26 & 0.26 & 0.32 \\
Return on total assets \% & 0.98 & 1.17 & 1.22 & 1.40 \\
Return on shareholders' right \% & 6.63 & 8.00 & 8.32 & 9.68 \\
Debt \% & 85.22 & 85.43 & 85.26 & 14.74 \\
Capital/assets \% & 14.78 & 14.57 & 27.97 & 85.38 \\
Capital/risk assets \% & 29.01 & 29.09 & & 14.62 \\
\hline
\end{tabular}

Source: Jordanian commercial banks annual reports.

\section{Copyrights}

Copyright for this article is retained by the author(s), with first publication rights granted to the journal.

This is an open-access article distributed under the terms and conditions of the Creative Commons Attribution license (http://creativecommons.org/licenses/by/3.0/). 